\title{
Innovative Regional Development of the Structurally Disadvantaged Industrial Region by means of the Local Currency
}

\author{
Aleksandr KLJUČNIKKOV ${ }^{1}$, Mehmet CİVELEK ${ }^{2 *}$, Vladimír KRAJČÍK ${ }^{3}$ \\ and Ivana ONDREJMIŠKOVA
}

Authors' affiliations and addresses:

Institute of Entrepreneurship and Marketing,

University of Entrepreneurship and Law,

Michálkovická 1810/181, 71000 Ostrava-Slezská

Ostrava, Czech Republic

e-mail: kliuchnikov@gmail.com

${ }^{2}$ Institute of Entrepreneurship and Marketing, University of Entrepreneurship and Law,

Michálkovická 1810/181, 71000 Ostrava-Slezská

Ostrava, Czech Republic

e-mail: m_civelek@windowslive.com

${ }^{3}$ Department of Information Technologies and Analytical Methods, University College of Business in Prague, Spálená 76/14, 11000 Nové Město,

Prague, Czech Republic

e-mail:krajcik@vso-praha.eu

${ }^{4}$ Department of Safety Studies, Faculty of Political Science and International Relations, Matej Bel

University in Banská Bystrica, Kuzmányho 1, 97401

Banská Bystrica, Slovakia

e-mail: ivana.ondrejmiskova@umb.sk

*Correspondence:

Mehmet Civelek, Institute of Entrepreneurship and Marketing, University of Entrepreneurship and Law, Michálkovická 1810/181, 71000 Ostrava-Slezská Ostrava, Czech Republic

tel.: +420773873403

e-mail: m_civelek@windowslive.com

Funding information:

Technology Agency of the Czech Republic

Grant Number TL02000562

Acknowledgement:

This research is a part of the scientific research project "Research of the potential of local currency's implementation for sustainable regional

development" funded by the Technology Agency of the Czech Republic TAČR, grant number (TL02000562).

How to cite this article:

Ključnikov, A., Civelek, M., Krajčík, V. and Ondrejmišková, I. (2020). Innovative Regional Development of the Structurally Disadvantaged Industrial Region by the Means of the Local

Currency. Acta Montanistica Slovaca, Volume 25 (2), 224-235

DOI:

https://doi.org/10.46544/AMS.v25i2.9

\begin{abstract}
Local and community currencies have been used as a stimulating tool to increase trading activities and social interactions of geographically restricted regions. This paper aims to investigate the potential of innovative regional development of the structurally disadvantaged industrial region focused on the steel and mining industry by means of the local currency. Being the important players of local economies and regional development, SMEs have always been in the center of interest for practitioners of the local and community currencies. Therefore, our research team analyzed and explored major benefits and barriers that SMEs perceive to adopt and use local currency. In parallel with the specified aims, the researchers employed the structured questionnaire survey with open and dichotomous questions focused on SMEs with no practical experience with the acceptance and use od the local or community currencies in Cieszyn Silesia region. The results of our research show that SMEs are prone to be active members of local currency communities, and they positively perceive the support that major regional producers, service providers, and practitioners can provide for them through this instrument. Moreover, some SMEs also perceive local currencies as a marketing and promotion tool that increases product-service quality and mutual transactions of firms. According to the respondents, high participation fees and exchange rates, lack of usage by customers and coverage by national currencies, counterfeiting, and fraud, liquidity risk, taxability, accountability, legislative and technical issues, credibility and trustworthiness of practitioners have been main impediments in the adoption and usage of these currencies by SMEs. This research provides innovative solutions and suggestions for policymakers in case of the regional development of the structurally disadvantaged industrial regions to overcome the barriers of local currencies. Since local currencies can be created in digital formats, the increasing importance of local digital currencies in the Covid-19 pandemic has also been highlighted.
\end{abstract}

\section{Keywords}

SMEs, regional development, local currency, community currency, digital currency, Covid-19, benefits, obstacles, Cieszyn Silesia region. 


\section{Introduction}

Regional development of the structurally disadvantaged industrial regions (Mohammadali \& Abdulkhaliq, 2019) is a field that needs a new and innovative approach. This paper aims to investigate the potential of innovative regional development of the structurally disadvantaged industrial region focused on the steel and mining industry by means of the local currency. Many studies also confirm the existence of regional disparities and inequalities regarding the economic and social conditions of individuals in various regions (Maličká, 2019; Svatošová, 2012; Netrdová \& Nosek, 2020).

Some indicators such as unemployment rates, and GDP per capita also differ in various regions of countries especially the regions close to capital cities, industrialized regions (Maličká, 2019; Svobodová et al., 2018) and borders (Sirohi et al., 2019; Churski \& Dominiak, 2014; Gajdová \& Tuleja, 2015). Sirohi et al. (2019) analyze the regions, including the locations next to the borders, and confirm that agricultural firms located to borders have lower performance levels than other regions. Similarly, Svobodová et al. (2018), Churski and Dominiak (2014), Gajdová and Tuleja (2015) state that regions that are close to borders do usually experience more economic issues and have lower economic power and conditions in comparison with other regions of nations. The border regions also face more problems to receive more income, attract more investments, and have more innovative actions (Svobodová et al., 2018). In this regard, the region that this research analyzes might be a good example. This is because Cieszyn Silesia is located in the Polish-Czech borderland, and it is a Euroregion. Moreover, this region has coal mines and carries importance for the steel industry (Olszewski, 2016).

Cieszyn Silesia region was formed by the collaboration of Stowarzyszenie Rozwoju i Współpracy Regionalnej "Olza in Poland and Regionální sdružení pro česko-polskou spolupráci Těsínského Slezska in the Czech Republic on 22 April, 1998 (Wróblewski, 2016; Olszewski, 2016). Since this region's location is at the borderland, it has some problems related to geography (Olszewski, 2016). This region is a mountainous region (Wróblewski, 2016) and, firms in the mountainous can face with some obstacles regarding transportation or cooperation (Dołzbłasz \& Raczyk, 2015; Svobodová et al., 2018). Moreover, the cities located next to PolandCzech borders also have some issues such as lack of industrialization, job opportunities, and population. These cities are located in highland regions that create a barrier to be developed, although it can provide benefits for regional tourism (Svobodová et al., 2018). Wróblewski (2016) investigates citizens of this region and find that industrialization, social policy, self-governance, and agriculture were perceived as main problems by these individuals regarding the conditions of Cieszyn Silesia. On the other hand, the lack of financial means and projects is one of the main problems experienced in this region. Although some organizations and local authorities have provided some financing opportunities for citizens and local firms, the amount of these funding options is not enough. Organizational and legal differences in these cross-border cities also create some difficulties for the development of this region (Olszewski, 2016). For these reasons, regions in Czech-Poland borders face more economic problems and have lower economic conditions than other regions in the Czech Republic and Poland (Svobodová et al., 2018; Churski \& Dominiak, 2014; Gajdová \& Tuleja, 2015).

To reduce these regional disparities and inequalities, some innovative implementations can be applied by local authorities, practitioners, or policymakers. In this regard, local currencies can be used as an innovative tool to overcome these issues. Local and community currencies are called as "monetary and grassroots innovations" that enable local citizens and firms to have new social and economic opportunities to reduce income inequalities (Huttunen \& Joutsenvirta, 2019; Seyfang \& Longhurst 2012; Benkler, 2017; Ryan-Collins, 2011; Chipere, 2018) and regional disparities by providing sustainable and regional development (Seyfang \& Longhurst 2013; Fesenfeld et al., 2015; Szemerédi, 2018). This is because national currencies might cause social and economic inequalities since they are under the control of policymakers and other strong players in the market, such as multinational firms (Carroll \& Bellotti, 2015). Therefore, especially in the era of economic crises, local and community currencies have been implemented by practitioners to overcome the negative impact of crises because of its influences on stabilization (Seyfang \& Longhurst, 2012) and stimulating role for economic power and social equality in various regions (De Filippi, 2015). Since these currencies also circulate in digital form by using new technological tools or methods as digital currencies do, this fact is also a strong argument to confirm its innovativeness. Local currencies are also called community currencies; thus, the term of community currency will also be used in this paper to remark local currencies (Civelek et al., 2019).

Community currencies circulate in restricted regions as a payment method; thus, they differ from national currencies (Shaw, 2018; Dini \& Kioupkiolis, 2019; Diniz et al., 2019; Kwon et al., 2019) and operate and are disbursed in meso-level mainly by close local citizens or firms (Dini \& Kioupkiolis, 2019). These currencies also enable its users to have a closer relationship by building societies, new methods of payments and exchange, providing new solutions for individuals to survive and increase local economic activities (Dittmer, 2013) and also local tourism activities ( $\mathrm{Vu} \&$ Ngo, 2019).

With the existence of the Covid-19 pandemic, digital payments and technologies have become more popular since they have enabled people to do transactions with required social distance, no physical contacts, and stay away from crowded places. Carrying coins and banknotes and making purchases by them have become 
more suspicious transactions, because of people's concerns that these materials can carry viruses (Gardner, 2020; Samantha, 2020; De' et al., 2020; Kakushadze \& Liew, 2020). Since digital currencies provide contactless transactions for payments, people might become more adapted to the new era's usage of these currencies. Therefore, focusing on both forms of local currency digital and paper-based makes this paper draw attention to a current topic and its importance in the Covid-19 pandemic.

Community currencies also encourage especially smaller enterprises to overcome financial issues that they face (Cannas, 2017). Dini and Kioupkiolis (2019) investigate one of the community currencies in Italy, namely, Sardex, and express that local currency provide economic and financial support for SMEs. For instance, when merchant users adopt the usage of these currencies for their sales, this fact also influences consumers' behaviors by making them perceive these currencies' usage more secure and guaranteed (Hartono et al. 2014; Roussou et al., 2019). In this case, businesses that are users of these currencies will also receive benefits by increasing the number of their customers and incomes (Roussou et al., 2019). Benefits that are provided by local currencies have also been analyzed by some researchers (Gao et al., 2016; Hur et al., 2015; Ly, 2013). However, different from these researches, this paper aims to investigate the perceptions of SMEs regarding benefits, incentives, and supports that practitioners and major local merchant users provide for users of local currencies. SMEs carry high importance for SMEs since they play a vital role in job creation (Ključnikov et al., 2019). SMEs that are analyzed by this paper are located in the specific region, which is located in Beskyd mountains, that this is a mining region of Silesia, with highly developed iron processing.

Although local currencies provide supports, incentives and other benefits for its merchant users such as SMEs, because of security issues such as fraud and counterfeiting (Gentilal et al., 2017; Abraham et al., 2019; Glaser et al., 2014; Walton \& Johnston, 2018), risk (Pianese et al., 2018; Beer \& Weber, 2015; Dupont \& Squicciarini, 2015; Gao et al., 2016; Hur et al., 2015; Ly, 2013), trust (Abraham et al., 2019; Shahzad et al., 2018), costs of exchange and membership (Pianese et al., 2018, Diniz et al., 2016; Diniz et al., 2019), accountability (Blanc \& Fare, 2013; Diniz et al., 2016; Diniz et al., 2019) and tax issues (Eisenstein, 2011; Seyfang, 2005), SMEs might become less interested in the usage of these currencies, and their adoption to the usage of these currencies might be reduced. In this regard, this paper also aims to indicate and explore major concerns of potential merchant users of local currency that might influence their adoption and usage. For these reasons, two main research questions can arise as follows; How do potential SMEs users perceive the benefits of local currency? How do potential SMEs users perceive obstacles of local currency that influence their usage of this currency?

Since this paper only focuses on potential business users of a local currency and looks at the benefits and constraints of local currencies from firms' perspectives, this paper differs from other studies. Moreover, the firms that this paper analyses have never experienced and adopted local currencies for their operations. For these reasons, this study can make practitioners, policymakers, entrepreneurs, and academicians interested in the results of this research. This is because, regarding the results of this paper, all players in the market can be aware of the fact that whether it is beneficial to implement a local currency for SMEs in a less developed region or not.

The rest of the paper is structured as follows. In section 2, the paper interprets the main points of this paper in detail by doing an extensive literature review and providing important information from other related studies. The data and the methods that this paper applies are clarified in the Data and Methodology section. Section 4 highlights the results of this paper. In section 5, the paper discusses the main results and provides potential reasons for the findings by enabling solutions for the problems that SMEs face in the usage of local currencies. Finally, the paper concludes the main results by summarizing other important facts about this research.

\section{Material}

\section{Material and Methods}

Implementing a local currency in a specific region, reduces income inequalities, poverty, being excluded from societies for individuals, and changes their buying behaviors, thus increasing productivity. All these facts also enable local currencies to play a trust-building role among communities and support local economic, social, environmental developments and sustainability in specified areas (Nishibe, 2018; Alia \& Spiegelman, 2020; Dini \& Kioupkiolis, 2019). Local currencies increase users' collective behaviors and increase their participation in common social activities by creating mutual trust among them (Diniz et al., 2019; Littera et al., 2017; Ruddick et al. 2015; Sanz, 2016; Alia \& Spiegelman, 2020). This is because they enable its users to have face to face interactions and payments, especially in a paper-based form (Ferreira et al., 2015; Diniz et al., 2019). Since local currencies provide their users to buy or sell products and services, players in trade such as sellers (firms) and buyers (consumers) have closer interactions even in digital form of these currencies (Miszczuk, 2018).

Although these studies highlight the trust-building role of local currencies, as already stated, the trustworthiness of these currencies has been one of the major concerns of merchant users. This is because the trustworthiness of these currencies is highly related to the protection and safety of private data (Mendoza-Tello et al., 2018). Since local currencies circulate independently and without the sovereignty of governments to buy or sell goods and services, private information and previous transactions of its users must not be disseminated. 
Otherwise, users might not have a willingness to use these currencies because of their security concerns (Hirotsugu et al. 2011; Hirotsugu et al. 2012), and they might experience the privacy and monetary losses (Roussou et al., 2019). When users' mutual relationships are based on trust, they become more satisfied to be participants or members of these currencies by perceiving local currencies as less risky (Alia \& Spiegelman, 2020).

People desire another party's existence to mediate between them and practitioners or merchant users of digital currencies to trust these currencies (Bashir et al., 2016). However, the nonexistence of third parties in digital currency transactions makes potential users reluctant to trust them. Therefore, the success of digital currencies and their adoption by users does not only depend on their practitioners' effective operations but also supports and collaborations of governments, local authorities and businesses carry high importance in implementations of these currencies (Kim et al., 2016).

Another concern of users of local currencies is about the exchange of these currencies with national currencies. Potential users perceive the exchange of these currencies as difficult procedures (Cato \& Suarez, 2012; Hirotsugu et al., 2011; Hirotsugu et al., 2012; Dini \& Kioupkiolis, 2019). Although some of the local currencies enable its users to convert them to national currencies without any expenses or fees (Mavromatidi et al., 2009; Gomez \& Helmsing, 2008; Kim et al., 2016) local currencies charge their merchant users by fees or apply some exchange rate that increases operational costs for potential merchant users (Kim et al., 2016). According to Ryan-Collins (2011), merchants can make redemption for their Stroud pounds and face a 5\% fee for this transaction. Aside from this fee, traders also face another cost: annual membership (Ryan-Collins, 2011). Similarly, Eusko is another example of a local currency that charges its users 5\% exchange rates as a fee. This fee is required by practitioners to defray the expenses of the local currency (Alia \& Spiegelman, 2020).

Another risk that potential users might perceive occurs when they use new technological tools or platforms for the first time (Lee, 2009; Walton \& Johnston, 2018). Some studies confirm that the propensity of informed potential users regarding these currencies is higher than that of other people who lack knowledge and ability to use digital currencies (Shahzad et al., 2018; Walton \& Johnston, 2018). Besides these problems, some other constraints exist in their widely adopted and usage by businesses (De Carrillo et al., 2018). Although incomes from local currencies are counted as taxable, taxes have to be paid in local currencies that create another obstacle for its users (Eisenstein, 2011; Seyfang, 2005). For this reason, some supplier firms do not accept trading in local currencies (Kim et al., 2016).

Concerning to benefits, incentives, subsidies and supports that practitioners or other players of local currencies provide, a discount is the first tool that comes to the mind. In some of the local currencies, practitioners support their firm users to make discounts for their customers when these consumer users buy products or services (Ryan-Collins, 2011). On the other hand, some of the local currencies also enable their business users to receive discounts from these currencies and redeem their customers with a charging rate. For instance, Eco-Pesa in Kenya has provided a $20 \%$ discount for businesses. When redeeming this currency, its firm users charge their customers by the rate of $20 \%$ (Ruddick et al., 2015). To encourage the usage of local currencies by businesses to do businesses to provide promotions and increase their awareness of local currencies, practitioners also apply discounts (North, 2010). Another example of community currency that provides subsidies or bonuses is Bangla-Pesa, and each registered business receives 400 Bangla Pesa, and half of this volume is provided by the community representatives (Ruddick et al., 2015).

Moreover, giving some bonuses when making more transactions with these currencies can serve for environmental purposes such as using it for public transportation, and the entrance of cinemas and swimming pools (Miszczuk, 2018). According to Brenes (2011), vouchers might be another example of provided incentives by local currencies. Since vouchers' usage does not make businesses face financial costs, these vouchers can be used for loan repayments with lower interest rates. Registered businesses might also use these currencies to buy raw materials or inputs for their production, to gain local services, to provide bonuses or to pay some part of wage of their workers (Brenes, 2011) and to set new relations with their suppliers that also use these currencies (Hammamia et al., 2014; Brenes, 2011).

Corresponding users' security concerns, practitioners also apply blockchain technologies that might provide more secure transactions for its users by creating trust between them without the help or intermediary role of financial organizations. França et al., 2020; Shaw, 2018). It also overcomes the problem of double-spending (Shaw, 2018). This is because the existence of cryptos in this technology secures the transaction by providing transparency and trustworthiness for its users. Moreover, this technology makes its users face reduced transaction costs that might stimulate and draw potential users' attention. Due to providing reduced costs and secured transactions, users can gain advantages in case of adopting its usage (Mendoza-Tello et al., 2018). 


\section{Methods}

This research purposes to shed light on the impacts of a local currency implementation in the regional development and perceptions of potential merchant users of a local currency regarding benefits, supports, risks, and obstacles of this novel payment method. Besides the benefits and supports provided by practitioners of local currencies, this paper also interprets the encouragements that trader users might provide for their employees and customers, thus local development. In line with these selected purposes, the researchers have created an online questionnaire survey to collect data. The survey includes 37 questions, and 12 are created to find the characteristics of the business and the respondents, such as work experience, age of respondents, legal form, and size of SMEs. The data collection process was performed from the end of 2019 until the beginning of 2020. The respondents of these surveys are the executives of 24 SMEs, such as owners (15 respondents), shareholders (3 survey participants) and CEOs, managers, and directors (6 respondents) of analyzed businesses. The sample of the current research analyses are SMEs that are located in the Beskyd mountains, which is a mining region of Silesia. None of these businesses have participated and used a local currency.

The top three open questions in Tab. 1 were directed to the respondents to fulfill the aims of this paper regarding benefits, risks, and obstacles of local currency. For this reason, this paper is a kind of descriptive research that provides opportunities for researchers to determine and explain respondents' attitudes and ideas under different circumstances (Saunders et al., 2009). Regarding the support and security of a local currency, dichotomous (yes, no), questions were applied to scale the questionnaires' responses.

Two hypotheses are set by following the study of Cepel et al. (2019). To test the H1 hypothesis, the responses from Q4 and Q5 are considered. On the other hand, the researchers pay attention to the responses of Q6 to evaluate the $\mathrm{H} 2$ hypothesis.

H1: More than $50 \%$ of the respondents think that the biggest employers in the region and the introduction of a local currency should be more supportive of regional producers and service providers.

$\mathrm{H} 2$ : More than $50 \%$ of the respondents assume that a secured local currency is an appropriate way to provide supports for firms.

Null hypotheses are set as less than $50 \%$ of the total respondents agree with the statements specified in $\mathrm{H} 1$ and $\mathrm{H} 2$ hypotheses.

Tab. 1. Measurements in the Questionnaire

\begin{tabular}{|c|c|}
\hline Constructs & Measurements \\
\hline Benefits & Q1- What do you see as the most significant benefits of the introduction of the local currency? \\
\hline Risk & Q2- What risks do you see in accepting your local currency? \\
\hline Other Obstacles & Q3- What are the other main obstacles you see in accepting your local currency? \\
\hline Support & $\begin{array}{l}\text { Q4- Do you agree that major regional employers should give greater support to regional producers and } \\
\text { service providers? } \\
\text { Q5- Do you agree with the opinion that the introduction of the local currency can significantly support } \\
\text { regional producers and service providers in the region of Těšín Silesia? }\end{array}$ \\
\hline Security & $\begin{array}{l}\text { Q6- Is the coverage of the local currency system by the Czech crown a sufficient guarantee of the } \\
\text { security and credibility of the entire system for you? }\end{array}$ \\
\hline
\end{tabular}

Concerning the structure of the sample, Table 2 is illustrated below:

Tab. 2. Sample profile

\begin{tabular}{cccc}
\hline \multirow{2}{*}{ Firm size } & Micro & $\mathrm{n}$ & Share \\
& Small\& medium & 18 & $75 \%$ \\
\multirow{2}{*}{ Gender } & Male & 6 & $25 \%$ \\
\hline \multirow{2}{*}{ Work exp } & Female & 14 & $58.3 \%$ \\
& Up to 10 years & 10 & $41.7 \%$ \\
\hline \multirow{2}{*}{ Age } & More than 10 years & 15 & $62.5 \%$ \\
& Up to 40 years old & 11 & $37.5 \%$ \\
\hline \multirow{2}{*}{ Education } & More than 40 & 13 & $54.16 \%$ \\
& Less than bachelors' & 9 & $37.5 \%$ \\
& Bachelors and more & 15 & $62.5 \%$ \\
\hline \multirow{2}{*}{} & Total & 24 & $100 \%$ \\
\hline
\end{tabular}


Most of these businesses are located in Třinec, Český Těšín, and Jablunkov in Těšín Silesia region, and 18 of them are local businesses while 6 firms also operate in other regions. One firm works under the legal structure of a Joint Stock company, 14 firms are sole proprietorships, 6 firms are limited liability companies, 3 of them are government-sponsored organizations.

\section{Results}

The findings from the survey bear out that although none of these businesses have participated and used a local currency, all businesses are interested in joining a local currency system to support their businesses. This is because they believe that they have goods and services that customers can buy with local currency. On the other hand, 8 of these businesses provide vouchers to their employees for a meal and other leisure activities, and 3 businesses pay around $8.99 \%$ commission to the providers when exchanging these vouchers to the national currency. Other SMEs pay 2.99\% (1 enterprise), 4.99\% (2 enterprises), and 6.99\% (2 enterprises) commission to exchange vouchers to Czech koruna.

To find the benefits of local currencies from the perspective of SMEs, the researchers ask an open question: What do you see as the biggest benefit of introducing the local currency? Most of the firms' executives state that local currencies provide supports for regions, entrepreneurs, and local businesses. Moreover, some of the respondents state that local currencies increase awareness of local products, services, businesses, and other regional possibilities. Some company executives also declare that money will be kept and only circulated in the region. One owner of an SME expresses that "Local currency provides support of regional subjects by their promotion, support of cohesion and patriotism in the region and support of the sustainable economy."

Concerning other benefits of local currencies, three respondents claim that "A local currency might be a useful tool for businesses' marketing activities." Increases in the quality of products and services, economic supports and development, close interactions between local producers, service providers and individuals, increasing nationalistic behaviors of individuals and their motives to make purchases in their regions, providing partial independence, sustainability, and ecological advantages are other benefits of a local currency that are perceived by SMEs.

Corresponding to the risks that are perceived by SMEs, high fees, and exchange rates of a local currency are the main concerns of the majority of SMEs' executives. Nine of investigated SMEs remark that when the exchange rate of the local currency to the Czech crowns is $6.99 \%$, they will accept the usage of these currencies. Moreover, the other 3 businesses accept 4.99\%, 4 firms accept 3.99\%, 4 SMEs accept 2.99\%, 2 enterprises accept $1.99 \%$, and a firm accepts $0.99 \%$, and another enterprise accepts $11.99 \%$ exchange rate when exchanging the local currency to the national currency of the Czech Republic. Another major risk that SMEs perceive in the analyzed region is the fear of firms' lack of local currency usage by their consumers. The executives also state counterfeiting of paper money, liquidity risks, lack of choices to use, and spend this currency as a risk of local currency. For instance, one of the owner's remarks that his firm cannot achieve higher sales when adopting the local currency. Some other firm executives also profess that it can be difficult to set the prices and make bookkeeping entries (accounting) when accepting the usage of these currencies for their operations and sales of goods and services.

When it comes to other obstacles that SMEs perceive in accepting local currency usage, some owners and managers state that legislation might be one of the main barriers when adopting a local currency. Two other company executives mention that their technical equipment can create some obstacles to accept the usage of local currency. Another executive highlights the fact that when firms do not have wide networks, it will be another constraint to be a member of this currency implementation.

Regarding the support of these currencies, all of the respondents agree that major regional employers should give greater support to regional producers and service providers. Similarly, all respondents also confirm the fact that the introduction of the local currency can significantly support regional producers and service providers in the region of Silesia. For these reasons, this paper supports the H1 hypothesis that assumed more than $50 \%$ of the respondents accept the statements mentioned above related to the support provided by local businesses and practitioners. This is because $100 \%$ of the analyzed SMEs agree with this fact.

With reference to SMEs' security concerns, 19 (79.16\% of the total respondents) respondents state that the coverage of the local currency system by the Czech crown is a sufficient guarantee of the security and credibility of the entire system for them. However, for the other 5 respondents, this is not sufficient. The credibility and trustworthiness of the practitioners of a local currency carry high importance for these businesses to feel secure when using local currency. Since more than $50 \%$ of the respondents $(79.16 \%)$ assume that a secured local currency is an appropriate way to provide support for firms, this research supports the $\mathrm{H} 2$ hypothesis. 


\section{Discussion}

This study's results regarding the perceived benefits of a local currency confirm that most SMEs have positive thinking about the local currency since this currency encourages regions, entrepreneurs, and local businesses. For this reason, this paper finds similar results with Diniz et al. (2019), Dini and Kioupkiolis (2019) since these studies also profess the positive contributions of local currencies on local businesses, regions, and entrepreneurs. Another benefit of a local currency perceived by SMEs is increasing awareness of local products, services, and businesses. This result of this research is also compatible with the remarks of Shaw (2018) and Miszczuk (2018). As stated in the Results section, some SMEs also perceive the following fact as a benefit; The local currency circulates in the specified region where it is adopted. This statement of SMEs also makes this research to be consistent with the arguments of Dini and Kioupkiolis (2019), Diniz et al., (2019), and Kwon et al. (2019) because these studies also posit the similar opinions of users of local currencies. Since local currency only circulates in the specified region, local SMEs can achieve higher performances by increasing their sales and trade volume. Thus, their revenues, investments, and productivities increase, and all these facts make them face with reduced financial obstacles to operate their firms.

Other benefits of a local currency that are positively perceived by analyzed SMEs are the usage of local currencies as a marketing tool, increasing social interaction between users, quality of goods and services, sustainability, partial independence, and volume of sales in the restricted regions. These benefits are also affirmed by Nishibe (2018), Alia and Spiegelman (2020), Hirotsugu et al. (2011), Hirotsugu et al., (2012), and North (2010). Therefore, this paper also has similar results to these studies. On the other hand, some of the results of this research object to the comments of Krohn and Snyder (2008) and Marshall et al. (2018). This is because of Krohn and Snyder (2008) and Marshall et al. (2018) state that a local currency does not make significant contributions to the local economic activities.

With reference to the risks of local currencies perceived by analyzed SMEs, high participation fees and exchange rates are some of the main risk factors for company executives. These results of this research are also compatible with the findings of Blanc and Fare (2013), Diniz et al. (2016), Pianese et al. (2018), Mavromatidi et al. (2009) because these researchers also mention high exchange rates and fees as a risk factor for potential users to adopt the usage of community currencies.

The findings of this paper regarding other risks factors such as lack of usage of local currencies by consumers, issues related with counterfeiting and fraud, and liquidity risk are also consistent with the studies De Carrillo et al. (2018), Gomez and Helmsing (2008) and Kim et al. (2016).

When it comes to other obstacles, risks and security issues, accounting, legislation, technical issues, and lack of coverage of local currencies by national currency are perceived as constraints in the wide usage of these currencies by merchant users. Hence, these results also confirm the fact that this paper has similar findings with Eisenstein (2011), Seyfang (2005), Cato and Suarez (2012), and Mendoza-Tello et al. (2018) regarding coverage, security, legislation and accounting issues of local currencies. Moreover, this paper also substantiates that practitioners' reliability and trustworthiness influence potential merchant users' perceptions regarding the security of local currencies. In this regard, practitioners' reputations can be a vital factor for potential users to feel secure when making adopting local currencies.

This is because having a good reputation increases the trustworthiness of community currencies (Krabbe, 2015; Alia \& Spiegelman, 2020). Similarly, when individuals are aware of a brand name or image of a business, they can positively perceive the discounts provided by practitioners depending on this brand and image (Gavurova et al., 2018). Thus, if individuals are familiar with a brand, its image, and reputation, their propensity to trust increases even the percentage of discount that the owner of this brand provides is high (Bacik et al. 2017; Lee et al., 2015). When looking from merchant users' perspective, if practitioners have a good reputation and image, their trustworthiness might be increased. Thus, SMEs can feel secure to adopt the usage of these currencies. Even practitioners of local currencies make discounts with a higher percentage to increase the usage of these currencies, potential users might become more suspicious, and practitioners might harm the brand image of these currencies. For instance, some currencies such as Totnes and Lewes stopped making discounts since participating firms had not satisfied with discounting practices.

Concerning supports, investigated SMEs contend that the existence of local currency in a region and endorsements of major regional firms motivate and stimulate regional producers and service providers, thus SMEs. Local currencies can also be used as microcredit, and cash (Majuri, 2019; Miszczuk, 2018; Shaw, 2018) notes, secure loans, unsecured loans, exchangeable vouchers, customer's loyalty currency (Miszczuk, 2018). By having such opportunities, merchant SMEs might become more interested in using these currencies to overcome financial impediments that they face and manage their liquidity risk (Bácsi \& Herczeg, 2014; Diniz et al., 2019). In the case of providing microcredits with lower interest rates, practitioners can also expand the usage of these currencies to large extents (Majuri, 2019). For instance, in its mutual credit system, Sardex also provides loans for SMEs with free of interest and without asking for collateral (Dini \& Kioupkiolis, 2019). Since these 
currencies are used as alternative payment methods in the financial system, practitioners of local currencies can collaborate with banks and can provide mutual credit or crowdfunding opportunities for their users by making financial empowerment (Diniz et al., 2019).

Besides the support of financial institutions and practitioners to increase awareness and usage of these currencies, governments' subsidies, incentives, and endorsements also play a fundamental role in solving the financial issues of SMEs and reducing their security and reliability concerns regarding local currencies. For example, when governments or local authorities create new rules regarding the usage of these currencies in local trade and add these rules to the regulations and taxes, merchant users might feel secure, and their trustworthiness might be increased (Roussou et al., 2019). On the other hand, if governments have a willingness to receive payments for fees and taxes in local currencies, the demand for local currencies might be increased, and this fact also causes some rises in local trade, production, and consumption (Mauldin, 2015). For these reasons, all major players' support is effective solutions for financial, security, risks, and trustworthiness concerns of SMEs regarding local currencies.

However, except for financial support, governments, local authorities, financing institutions, and practitioners should also provide some educational and administrative support for SMEs' executives to increase the awareness and usage of these currencies. By providing some courses, policymakers can also make businesses informed about the financial, social, and environmental benefits of local currencies. All these facts and supports can also make SMEs quickly adapted to use these currencies for their operations and make positive contributions to the regional development of restricted areas. As local currencies can be created in digital form, in this age, while people try to survive against the Covid-19 pandemic, SMEs can use this digital payment method as a promotion tool to make their consumers make more purchases from their products and services.

\section{Conclusions}

Due to having lack of internal financial sources and having problems with their credibility to receive financing opportunities from external institutions such as banks, most of SMEs encounter various financing difficulties. Since local currencies provide alternative solutions to make SMEs cope with these obstacles, their perceptions regarding the benefits of local currencies are of vital importance for their survival, thus, regional developments. Regional developments in cross-border regions also have vital importance since they are less developed and face more economic and social problems. In this regard, local currencies might provide innovative solutions to make local SMEs more powerful in reducing regional differences. However, SMEs might also be disinterested in the usage of these currencies. Thus, this paper aims to find the perceived benefits of local currencies for local SMEs; thus, regional developments and determines to explore the barriers that reduce the adoption of these currencies by SMEs. Since SMEs are vital players of regional development, focusing these facts make policymakers and local authorities to find alternative solutions to develop their regions.

To hit the aims of this paper and collect the data, the researchers created a questionnaire survey and directed them to firms' executives working for SMEs in the Beskyd mountains, a mining region of Silesia. Open questions were employed by researchers to be informed about the perspectives of 24 SMEs regarding benefits, risks, and other main obstacles of local currencies. On the other hand, dichotomous (yes, no), questions were asked to the respondents to see how SMEs perceive supports and security issues of these currencies. None of the analyzed firms has used or adopted these currencies, but all of them are willing to use it. All firms also positively perceive the supports that potential users and practitioners can provide for other potential users. Some firms also state that local currencies can provide effective ways to be used in their marketing activities, improve their goods and services, and their relationship with other businesses and consumers.

When it comes to obstacles that SMEs perceive, costs of exchange and membership, lack of convertibility to national currencies, a high number of disinterested consumers, security issues such as counterfeiting and fraud, issues such as taxing, liquidity, accounting, legislation and technical problems and reliability of practitioners have been main concerns of potential merchant users to accept the usage of local currencies for their operations. These concerns might be reduced with the good reputation and image of local currencies, collaborations of practitioners with financing institutions and governments, usage of these currencies as microcredit, unsecured loans or vouchers with reduced interest rates, less volume of required collaterals and reduced costs, the existence of governments' rules related with their accountability and taxability and the existence of educations and administrative supports. Moreover, using local currencies in digital form can make business users and individuals be more interested in these currencies due to facing with the Covid-19 pandemic. Since digital money can provide contactless transactions, potential users might prefer using this digital currency instead of using national currencies in paper-based form. These results provide opportunities for policymakers to apply the required precautions to support SMEs, thus, regional development.

By focusing on the SMEs' points of view regarding benefits, supports, incentives, risks, security issues, and other main obstacles of local currencies, this paper creates significant value addition to the related academic literature. However, this study has some limitations, especially regarding sample size. The sample that this paper 
analyses only consists of 24 SMEs. Moreover, this study only analyses SMEs that have been operating in a restricted region. This study also does not consider any characteristics of firms or executives to make comparisons between them. In this regard, further studies can include more firms in their samples by also considering some larger enterprises' perceptions. Researchers can also analyze businesses from different countries with different characteristics. New papers can also compare respondents' characteristics to find differences between respondents' perceptions regarding the benefits and impediments of local currencies.

\section{References}

Abraham, J., Sutiksno, D. U., Kurniasih, N., \& Warokka, A. (2019). Acceptance and Penetration of Bitcoin: The Role of Psychological Distance and National Culture. SAGE Open. https://doi.org/10.1177/2158244019865813

Alia, H. \& Spiegelman, E. (2020). Convertible local currency and trust: 'It's Not You, It's Me' - A field experiment in the French Basque Country Local Economy, 1-16. DOI: 10.1177/0269094220905505

Bácsi, J., \& Herczeg, I. (2014). Local currency as a tool of risk management in the small and medium enterprises sector. Roczniki Naukowe Stowarzyszenia Ekonomistów Rolnictwa i Agrobiznesu, 16(3), 18-23.

Bacik, R., Nastisin, L., \& Gavurova, B. (2017). The role of social media in the light of building a strong online brand awareness. In: Proceedings of the 5th International Conference Innovation Management, Entrepreneurship and Sustainability. 5th International Conference Innovation Management, Entrepreneurship and Sustainability (IMES). Edited by: Dvoulety, O; Lukes, M; Misar, J. Prague, May 25-26, 2017, pp. 38-47.

Bashir, M., Strickland, B., \& Bohr, J. (2016). What motivates people to use Bitcoin? In Y-Y. Ahn, \& E. Spiro (Eds.), Social Informatics - 8th International Conference, SocInfo 2016, Proceedings (pp. 347-367). Springer-Verlag. https://doi.org/10.1007/978-3-319-47874-6_25

Beer, C., \& Weber, B. (2015). Bitcoin - The promise and limits of private innovation in monetary and payment systems. Monetary Policy and the Economy, Q4/2014, 53-66. Available at https://ssrn.com/abstract $=2556800$

Benkler, Y. (2017). Peer Production, the Commons, and the Future of the Firm. Strategic Organization 15 (2): 264-274. doi:10.1177/1476127016652606.

Blanc, J., \& Fare, M. (2013). Understanding the role of governments and administrations in the implementation of community and complementary currencies. Annals of Public and Cooperative Economics, 84(1), 6381.

Brenes, E. (2011). Complementary currencies for sustainable local economies in Central America. International Journal of Community currency research, 15. doi: 10.15133/j.ijccr.2011.018.

Cannas, R. (2017). Embedding social values in tourism management: community currencies as laboratories of social entrepreneurship? In D. Dredge \& S. Gyimóthy (Eds). Collaborative Economy and Tourism. Tourism on the Verge. Springer, Cham. doi: 10.1007/978-3-319-51799-5_13.

Carroll, J. M., \& V. Bellotti (2015). Creating Value Together: The Emerging Design Space of Peer-To-Peer Currency and Exchange. In Proceedings of the 18th ACM Conference on Computer Supported Cooperative Work \& Social Computing, 1500-1510. New York, NY: ACM. doi:10.1039/c4sm02053g.

Cato, M., \& Suarez, A. M. (2012). Stroud pound: A local currency to map, meas-ure and strengthen the local economy. International Journal of Community Currency Research, 16. doi: 10.15133/j.ijccr.2012.017.

Cepel, M., Kljucnikov, A., Kozubikova, L., \& Krajcik, V. (2019). Local Currency as a Mean of Regional Competitiveness Development. Journal of Competitiveness, 11(4), 22-39. https://doi.org/10.7441/ joc.2019.04.02

Chipere, M. (2018). Virtual currency as an inclusive monetary innovation for the unbanked poor Electronic Commerce Research and Applications $28,37-43$.

Churski, P. \& Dominiak, J. (2014). The impact of innovations on growth and stagnation regions in Poland. European Planning Studies, 22(6): 1143-1164.

Civelek, M., Ključnikov, A., Krajčík, V., Žufan, J. (2019). The Importance of Discount Rate and Trustfulness of A Local Currency for the Development of Local Tourism. Journal of Tourism and Services, 10(19): 7792. https://doi.org/10.29036/jots.v10i19.117

De', R., Pandey, N., \& Pal, A. (2020). Impact of Digital Surge during Covid-19 Pandemic: A Viewpoint on Research and Practice. International Journal of Information Management, 102171. Advance online publication. https://doi.org/10.1016/j.ijinfomgt.2020.102171

De Carrillo, C. I. P., Esteva, J. L. R., Pena, P. N. C., \& Pharow, P. (2018). Identification of barriers and solutions for adoption of social, complementary and/or virtual currencies. International Journal of Community currency Research, 22. doi:10.15133/j.ijccr.2018.020. 
De Filippi, P. (2015). Translating Commons-Based Peer Production Values into Metrics: Toward CommonsBased Cryptocurrencies. In Handbook of Digital Currency: Bitcoin, Innovation, Financial Instruments, and Big Data, edited by D. Lee and K. Chuen, 463-483. Singapore: Elsevier Science \& Technology.

Dini, P. \& Kioupkiolis, A. (2019). The alter-politics of complementary currencies: The case of Sardex Politics \& International Relations, Cogent Social Sciences $\quad$ (2019), 5: 1646625 https://doi.org/10.1080/23311886.2019.1646625

Diniz, E. H., Cernev, A. K., \& Nascimento, E. (2016). Mobile social money: An exploratory study of the views of managers of community banks. Revista de Administração, 51(3), 299-309.

Diniz, E. H., Siqueira, E. S. \& Van Heck, E. (2019). Taxonomy of digital community currency platforms, Information Technology for Development, 25:1, 69-91, DOI: 10.1080/02681102.2018.1485005

Dittmer, K. (2013). Local currencies for purposive degrowth? A quality check of some proposals for changing money as usual. Journal of Cleaner Production, 54(1), 3-13. DOI: 10.1016/j.jclepro.2013.03.044

Dołzbłasz, S. \& Raczyk, A. (2015). Different Bordera - Different Cooperation? Transborder Cooperation in Poland. Geographical Review, 105(3): 360-376.

Dupont, J., \& Squicciarini, A. C. (2015). Toward de-anonymizing Bitcoin by mapping users location. Paper presented at the Proceedings of the 5th ACM Conference on Data and Application Security and Privacy. https://doi.org/10.1145/2699026.2699128

Eisenstein, C. (2011). Sacred Economics: Money, Gift, and Society in the Age of Transition Paperback. Evolver Editions.

Ferreira, J., Perry, M., \& Subramanian, S. (2015, February). Spending time with money: From shared values to social connectivity. In Proceedings of the 18th ACM conference on computer supported cooperative work \& social computing (pp. 1222-1234). Vancouver, BC: ACM.

Fesenfeld, L., Stuckatz, J., Summerson, I., Kiesgen, T., Ruß, D. \& Klimaschewski, M. (2015). It's the motivation, stupid! The influence of motivation of secondary currency initiators on the currencies' success. International Journal of Community Currency Research, 19, 165-172.

França, A.S.L., Amato Neto, J., Gonçalves, R.F. \& Almeida, C.M.V.B. (2020). Proposing the use of blockchain to improve the solid waste management in small municipalities, Journal of Cleaner Production, 244, https://doi.org/10.1016/j.jclepro.2019.118529.

Gajdová, K. \& Tuleja, P. (2015). Analysis of the Economically Active Population in the Czech-Polish Border Regions. International Journal of Information and Education Technology, 5(3): 237-241.

Gao, X., Clark, G. D., \& Lindqvist, J. (2016). Of two minds, multiple addresses, and one ledger: Characterizing opinions, knowledge, and perceptions of Bitcoin across users and non-users. Paper presented at the Proceedings of the 2016 CHI Conference on Human Factors in Computing Systems. https://doi.org/10.1145/2858036.2858049

Gavurova, B., Bacik, R., \& Fedorko, R. (2018). Analytical View of Online Marketing Tools in the Dimension of Marketing Campaigns' Personalization in Slovakia. Marketing and Management of Innovations, 2, pp. 186-200. doi: 10.21272/mmi.2018.2-15

Gardner, B. (2020). Dirty banknotes may be spreading the coronavirus, WHO suggests. March 2, Retrieved June, 20, 2020, from The Telegraphhttps://www.telegraph.co.uk/news/2020/03/02/exclusive-dirtybanknotes-may-spreading-coronavirus-world-health/.

Gentilal, M., Martins, P., \& Sousa, L. (2017). TrustZone-backed bitcoin wallet. Paper presented at the Proceedings of the Fourth Workshop on Cryptography and Security in Computing Systems. https://doi.org/10.1145/3031836.3031841

Glaser, F., Zimmermann, K., Haferkorn, M., Weber, M. C., \& Siering, M. (2014). Bitcoin - Asset or currency? Re-vealing users' hidden intentions. Retrieved from https://ssrn.com/abstract $=2425247$

Gomez, G., \& Helmsing, A. (2008). Selective spatial closure and local economic development: what do we learn from the Argentine local currency systems? World Development, 36(11), 2489-2511. https://doi.org/10.1016/j.worlddev.2007.11.015

Hammami, R., Temponi, C., \& Frein, Y. (2014). A scenario-based stochastic model for supplier selection in global context with multiple buyers, currency fluctuation uncertainties, and price discounts. European Journal of Operational Research, 233, 159-170. http://dx.doi.org/10.1016/j.ejor.2013.08.020

Hartono,E., Holsapple, C. W., Kim, K., Na, K. \& Simpson, J. T. (2014). Measuring perceived security in B2C electronic commerce website usage: A respecification and validation, Decision Support Systems, 62, 1121, https://doi.org/10.1016/j.dss.2014.02.006.

Hirotsugu, K., Yoshiaki, T., Naoya, K., Tetsuya, M. \& Kazuhiro, S. (2011). A local currency system reflecting variety of values. 2011 IEEE/IPSJ International Symposium on Applications and the Internet. DOI 10.1109/SAINT.2011.104

Hirotsugu, K., Yoshiaki, T., Tetsuya, M., Masato, N., Hideyuki, K. \& Sumiko, M. (2012). A local currency system reflecting variety of values with a swarm intelligence. 2012 IEEE/IPSJ 12th International Symposium on Applications and the Internet. 
Hur, Y., Jeon, S., \& Yoo, B. (2015). Is Bitcoin a viable e-business? Empirical analysis of the digital currency's speculative nature. Paper presented at the Thirty Sixth International Conference on Information Systems.

Huttunen,J. \& Joutsenvirta, M. (2019) Monies, economies and democracy: cultivating ambivalence in the codesign of digital currencies, CoDesign, 15:3, 228-242, DOI: 10.1080/15710882.2019.1631352

Kakushadze, Z. \& Liew, J. K. (2020). Coronavirus: Case for Digital Money? World Economics 21(1) (2020) 177-190. arXiv:2005.10154 [q-fin.GN]

Ključnikov, A., Civelek, M., Čech, P. \& Kloudová, J. (2019). Entrepreneurial orientation of SMEs' executives in the comparative perspective for Czechia and Turkey. Oeconomia Copernicana, 10(4), 773-795. doi: 10.24136/oc.2019.035

Kim, S. M., Lough, B., \& Wu, C.-F. (2016). The conditions and strategies for success of local currency movements. Local Economy, 31(3). doi: 10.1177/0269094216637332.

Krabbe, R. (2015). Building trust: Exploring the role of community exchange and reputation. International Journal of Community Currency Research 19(D): 62-71.

Krohn, G. \& Snyder, A. (2008). An economic analysis of contemporary local currencies in the United States. International Journal of Community Currency Research. Vo, (22), pp. 53-68.

Kwon, M., Lee, C., Xiao, Y., \& McIntosh, W. A. (2019). Community currency activities, community attachment, and quality of life: A case study of the Crooked River Alliance of TimeBanks. Time \& Society, 28(3), 1181-1220. https://doi.org/10.1177/0961463X17716737

Lee, M.-C. (2009). Factors influencing the adoption of internet banking: An integration of TAM and TPB with perceived risk and perceived benefit. Electronic Commerce Research and Applications, 8(3), 130-141. https://doi.org/10.1016/j.elerap.2008.11.006

Lee, S. H., Bai, B., \& Murphy, K. (2012). The role demographics have on customer involvement in obtaining a hotel discount and implications for hotel revenue. Management Strategy. Journal of Hospitality Marketing \& Management, 21(5). doi: 10.1080/19368623.2012.682622.

Lee, K., Lee, B. \& Oh, W. (2015). Thumbs up, sales up? The contingent effect of Facebook likes on sales performance in social commerce. Journal of Management Information Systems, 32(4). doi: 10.1080/07421222.2015.1138372.

Li, L., Rhee, C., \& Moon, J. (2018). Identifying the effect of product types in the relationships between product discounts and consumer distrust levels in China's online social commerce market at the era of big data. KSII Transactions on Internet And Information Systems, 12(5). doi: 10.3837/tiis.2018.05.016.

Littera G, Sartori L, \& Dini P. (2017). From an idea to a scalable working model: Merging economic benefits with social values in Sardex. International Journal of Community Currency Research 21: 6-21.

Ly, M. K.-M. (2013). Coining Bitcoin's legal-bits: Examining the regulatory framework for Bitcoin and virtual currencies. Harvard Journal of Law \& Technology, 27(2), 587-608.

Majuri, Y. (2019), "Overcoming economic stagnation in low-income communities with programmable money", Journal of Risk Finance, Vol. 20 No. 5, pp. 594-610. https://doi.org/10.1108/JRF-08-2019-0145

Maličká, L. (2019). Fiscal Decentralization And Regional Disparities In Czechia And Slovakia: Regression Analysis At The Nuts 2 And Nuts 3 Level. Scientific Papers of the University of Pardubice, Series D: Faculty of Economics and Administration, SciPap 2019, 27(3), 1007, 91-101.

Marshall, A. P., \& O'Neill, D. W. (2018). The Bristol pound: a tool for localization? Ecological Economics, 146. doi: 10.1016/j.ecoleon.2017.11.002.

Mauldin, R. L. (2015). Local currency for community development: Policy barriers and support. Journal of Community Practice, 23(3-4). doi: 10.1080/10705422.2015.1091420.

Mavromatidi,V. M., Gravas, E. M., Metsiou, A. X., Kostas, P., Zissopoulos, D. A., \& Mavromatidis, I. G. (2009). A Digital community local currency to restore overturned banks of money and ethic, our answer to worldwide credit crisis. Proceedings Of The 3rd International Conference On Communications And Information Technology, 203-206.

Mendoza-Tello, J. C., Mora, H., Pujol-López F. A\& Lytras, M. D. (2018). "Social Commerce as a Driver to Enhance Trust and Intention to Use Cryptocurrencies for Electronic Payments," in IEEE Access, vol. 6, pp. 50737-50751, 2018.

Miszczuk, M. (2018). Local currencies as an instrument for implementing the concept of sustainable development. Problems Of Sustainable Development, 13(2), 83-90.

Mohammadali, Z. M., Abdulkhaliq S. S. (2019). Prospects and Challenges of Entrepreneurship Development in the Kurdistan Region of Iraq: An Overview. International Journal of Entrepreneurial Knowledge, 7(2), 416. doi: $10.12345-0006$

Netrdová, P. \& Nosek, V. (2020). Spatial Dimension of Unemployment: Space-Time Analysis Using Real-Time Accessibility in Czechia. International Journal of Geo-Information, ISPRS Int. J. Geo-Inf. 2020, 9, 401; doi:10.3390/ijgi9060401.

Nishibe, M. (2018). Understanding the diversity of CCS world-wide in globalization and deindustrialization as an evolutionary tree diagram. International Journal of Community Currency Research 22: 16-36. 
North, P. (2010). Local Money - How to make it happen in your community, Tran-sition Books. Totnes, Devon: UIT Cambridge Ltd.

Olszewski, M. (2016). The Benefits and Challenges for Cross-border Cooperation in the Cieszyn Silesia Euroregion. The Journal of Cross Border Studies in Ireland 2016, retrieved from http://crossborder.ie/site2015/wp-content/uploads/2015/11/CCBS-JOURNAL-2016.pdf\#page=43

Pianese, F., Signorini, M. \& Sarkar, S. (2018). "Small Transactions with Sustainable Incentives," 20189 th IFIP International Conference on New Technologies, Mobility and Security (NTMS), Paris, 2018, pp. 1-5.

Roussou, I., Stiakakis, E., \& Sifaleras, A. (2019). An empirical study on the commercial adoption of digital currencies. Information Systems and e-Business Management (2019) 17:223-259. https://doi.org/10.1007/s10257-019-00426-7

Ruddick, W. O., Richards, M., \& Bendell, J. (2015). Complementary currencies for sustainable development in Kenya: the case of the Bangla-Pesa. International Journal of Community Currency Research, 19. doi: $10.15133 /$ j.ijccr.2015.003.

Ryan-Collins, J. (2011). Building local resilience: the emergence of the UK transition currencies. International Journal of Community Currency Research, 15. doi: 10.15133/j.ijccr.2011.023.

Samantha, M. K. (2020). Dirty money: The case against using cash during the coronavirus outbreak. March 7 , Retrieved June, 21, 2020, fromCNNhttps://www.cnn.com/2020/03/07/tech/mobile-paymentscoronavirus/index.html.

Sanz, E. O. (2016). Community currency (CCs) in Spain: an empirical study of their social effects. Ecological Economics, 121. doi: 10.1016/j.ecolecon. 2015.11.008.

Saunders, M., Lewis, P., and Thornhill, A. Research methods for business students. India, Pearson Education, 5 th edition, 2009.

Seyfang, G. (2005). Community currencies and social inclusion: A critical evaluation. CSERGE Working Paper EDM, No. 05-09, University of East Anglia, The Centre for Social and Economic Research on the Global Environment (CSERGE), Norwich.

Seyfang, G., \& N. Longhurst (2012). Money, Money, Money? A Scoping Study of Grassroots Complementary Currencies for Sustainability. 3S Working Paper 2012-02. Norwich: Science Society and Sustainability Research Group. doi:10.1094/PDIS-11-11-0999-PDN.

Seyfang, G. \& Longhurst, N. (2013). Desperately seeking niches: Grassroots innovations and niche development in the community currency field. Global Environmental Change 23 (2013) 881-891.

Shahzad, F., Xiu, G., Wang, J., \& Shahbaz, M. (2018). An empirical investigation on the adoption of cryptocurrencies among the people of mainland China. Technology in Society, 55. doi: 10.1016/j.techsoc.2018.05.006.

Sirohi, J., Kukalová, G. \& Moravec, L. (2018). Analysis of Regional Disparities in Agriculture Focusing on Economically Weak Regions of the Czech Republic. Scientia agriculturae bohemica, 50, 2019 (2): 141153.

Shaw N. (2018) Helping the Local Community with Crypto-Currency: A Case Study. In: Nah FH., Xiao B. (eds) HCI in Business, Government, and Organizations. HCIBGO 2018. Lecture Notes in Computer Science, vol 10923. Springer, Cham

Svatošová, L. (2012). The development of regional disparities in Czech Republic over the 2005-2010 years. Acta Universitatis Agriculturae et Silviculturae Mendelianae Brunensis 60(7), pp. 337-344. DOI: 10.11118 /actaun201260070337

Svobodová, J., Dömeová, L., \& Jindrová, A. (2018). Economic Differences Of Border Regions In The Czech Republic. Acta Universitatis Agriculturae Et Silviculturae Mendelianae Brunensis, 66(2), https://doi.org/10.11118/actaun201866020571

Szemerédi, E. (2018). An attempt to categorize Hungarian community currencies. Deturope, 10(1), 144-159.

Wróblewski, L. (2016). Creating an image of a region - Euroregion Beskydy and Euroregion Cieszyn Silesia examples. Economics and Management, 8(1), 91-100.

Vu, H.M, Ngo, V.M.. (2019). Strategy Development from Triangulated Viewpoints for a Fast Growing Destination Toward Sustainable Tourism Development - A Case Of Phu Quoc Islands in Vietnam, Journal of Tourism and Services 10(18): 117-140. https://doi.org/10.29036/jots.v10i18.86

Walton, A., \& Johnston, K. (2018). Exploring perceptions of bitcoin adoption: The South African virtual community perspective. Interdisciplinary Journal of Information, Knowledge, and Management, 13, 165182. https://doi.org/10.28945/4080 